\title{
INTERNATIONAL ENTREPRENEURSHIP AT A LEADING BRAZILIAN SOFTWARE SERVICES PROVIDER: THE CASE OF CI\&T
}

Sylvia T. de Almeida Moraes $^{1}$, Angela da Rocha

Pontifícia Universidade Católica do Rio de Janeiro - PUC/RJ, Rio de Janeiro, (Brasil)

\section{ARTICLE DETAILS}

\section{Article history:}

Received: 16 October 2018

Accepted: 21 August 2019

Available online January: 01 th 2020

Double Blind Review System

Scientific Editor

Ilan Avrichir

\section{Key words}

Entrepreneurship

Emerging countries

Internationalization

Software Industry

Brazil

\begin{abstract}
Objective: This case aims at discussing to what extent a company from an emerging country, Brazil, can become a major player on the global stage of the software industry.

Method: Teaching case, based on personal interviews with top executives and secondary data.

Main results: CI\&T is one of the most successful Brazilian IT companies in establishing a position in foreign markets. The case offers a detailed description of the internationalization process of the firm and discusses how the firm can develop its internationalization, facing the challenges and opportunities for further expansion.

Relevance/originality - This teaching case offers a real situation of an IT company from Brazil that developed a successful international strategy.

Theoretical / Methodological Contributions - The case contributes to foster the understanding of the three major liabilities of companies from emerging countries - liabilities of foreignness, liabilities of outsidership and liabilities of smallness. Social / management contributions - The case can be used in International Business courses to improve managerial skills of students and executives.
\end{abstract}

\section{Introduction}

$\mathrm{Cl} \& \mathrm{~T}$ is an information technology (IT) company based in the city of Campinas, Brazil. It specializes in outsourcing, developing and integrating applications. By 2016, the firm had operations in Brazil and in five other countries: the U.S. (offices in New York, Philadelphia, Atlanta and Somerset, and San Francisco), England, Australia, Japan and China, with around $10 \%$ of its 2,000 employees located abroad. Close to $50 \%$ of its turnover comes from international operations, mostly from the U.S. (27\%).

Despite its accelerated growth and internationalization, Cl\&T was still far from realizing its ambitions to become a globally relevant company in the IT industry. In addition, the economic crisis in Brazil since the end of 2014 threatened the company's growth in the coming years - one more factor to be considered to motivate the company to reduce its dependence on the domestic market. Therefore, the company's management was faced with the need to expedite the internationalization process, particularly with respect to activities to attract new and post-sale clients. Bruno Guiçardi,
President of the CI\&T's U.S. subsidiary noted: "CI\&T is a really ambitious company. We believe we can be one of the best in the world at what we do. So it's our desire to show that competence, to prove that mission, to win the game here, in Europe... wherever the game is being played."

\section{The Early Years}

In 1995, Cesar Gon and Fernando Matt, recent graduates in engineering from one of the best Brazilian universities, learned of a competition that IBM was sponsoring for a project. Bruno Guiçardi, who became a partner in 1997, described the emergence of the company:

"CI\&T was founded because of an opportunity that arose at IBM to compete in a project in which the two partners had expertise in the area. One of them was already working there under contract, and he heard about the opportunity. So he asked his manager if he could open a company to compete for the project. Would he consider us? He said yes. So we formed the company and won. That is how CI\&T began: with that project."

\footnotetext{
${ }^{1}$ Contact of the author Email: sylvia.tamoraes@gmail.com
} 
The project involved IBM's laboratories in Brazil and in France and the United States, forcing CI\&T to work in an international environment from the start. In 1998, however, the IBM's development center in Campinas, Cl\&T's largest customer, closed its doors. It was one of the effects of the crisis that hit IBM worldwide, forcing it to lay off employees and cancel contracts. As a result, CI\&T had to reinvent itself. Bruno Guiçardi explained:

\begin{abstract}
"It was a huge crisis. The company had thirty-odd employees, and in just one month $80 \%$ of its revenues, which came from IBM at the time, disappeared. We had to do something else: go to the market, for real. 'Let's learn how to sell.' So... it was a time of real learning. And we actually pulled it off. We managed to sell new projects; we didn't have to fire anyone; we were able to keep the entire team... We directed the company to make systems via the internet, which was just starting out in Brazil: e-commerce, and businessto-business. It was really new at that time to talk about internet systems. The company specialized itself and tried to discover new technological trends in order to stay ahead of the market. We've been doing that ever since."
\end{abstract}

Their contact with IBM, a world leading company, made the entrepreneurs realize they had the potential to develop software with an international quality standard. Guiçardi explained:

\begin{abstract}
"So we got the idea that 'Wow, we can do even better than IBM!' And what inspired us was that learning experience during the first three years. That's what created that little inner 'virus' that 'we can be an even better company than IBM; even better than the company that is considered to be the best in the world.' Our company was founded to really be a company that made a difference. And we are striving to accomplish this mission: being one of the best companies in the world in software development."
\end{abstract}

Hence, experience gave the partners confidence in their capabilities and it awakened their ambition to compete in the global market and not be restricted to Brazil. Even so, from 1998 to 2003, the company grew just in the domestic market. It was only in 2004 that CI\&T started to export. That same year, it became a privately-held corporation. Accelerated growth brought problems because the company had no structure to grow. As a result, it could not adequately meet delivery deadlines, which led to a reorganization of its structure. Márcio Cyrillo, an executive director at CI\&T responsible for global marketing operations, recalled the impacts of growth on the organization (Cyrillo, 2014):

\begin{abstract}
"But as we grew from hundreds of employees to half a thousand and later to more than a thousand, and our projects were large scale software implementations for Fortune 100 companies, reality started to wake us up. We realized we were more 'fragile' than 'agile'. We needed to carefully take into consideration the firm's scale and constraints. The challenge was how to make information and decision making processes work in an environment where it is just impossible to have all stakeholders in the daily meetings."
\end{abstract}

Government support has helped the company to expand. Between 2002 and 2005, the company had access to subsidized loans of 2.3 million dollars to invest in product and business development as well as to expand production capacity, under the program for the development of the national software industry. In addition, CI\&T received the backing of BNDES (Brazilian National Development Bank) in 2007 with the issuance of preferred shares in the amount of 7.6 million dollars, and an additional loan of around one million dollars. This was followed by a series of subsidized loans totaling over 20 million dollars between 2010 and 2016.

In $2009 \mathrm{Cl} \& \mathrm{~T}$ acquired Bl-One, a consulting services company for the implementation of analytical systems. In the same year, the company partnered with Google to offer smart computing solutions on a mobile platform. This partnership helped CI\&T to expand its operations in the U.S. The results also enabled the company to win an international competition to develop a system for Coca-Cola for the 2014 World Cup. The project used the Google Cloud Platform, and consisted of a Happiness Flag, a mosaic made up by thousands of crowd-sourced images send by fans that was unveiled in the opening of the event. In 2012, the company announced a partnership with the American firm Vistex, a provider of complementary SAP solutions. In 2014, the firm created a new area, CI\&T Digital, to integrate mobile, cloud computing, analytics and social technologies. In 2015 Cl\&T announced a partnership in the area of e-commerce with the multinational Hybris, a SAP company that provides ecommerce solutions using an omni-channel platform.

In 2010 the company was regarded as the most innovative company in the Best Innovator ranking, published by the global consulting firm A.T. Kearney 
and a Brazilian business magazine. In 2015, the company was placed 5 th in the overall ranking of the $100+$ Innovators in the use of IT, and first in the Technology Providers Award offered jointly by ITMedia and PWC in 2015. It was also ranked 68th in 2012 and 72nd in 2013 in the world rankings of the best providers of outsourcing services (The Global Outsourcing 100) by Fortune magazine.

In 2014 it was chosen Google Partner of the Year for Cloud Platforms and Gartner Cool Vendor. In
2015, the company was named by Forrester Research one of the most significant midsize providers of mobile enterprise application services and a strong performer. In 2016 it received Google's award as the "Most Googley Cloud Partner of the Year."

The growth achieved by the company displayed strong acceleration (Figure 1), from 2005 on. By 2015, total revenues neared 350 million BRL (approximately 90 million USD). In recent years $\mathrm{CI}^{\mathrm{T}} \mathrm{T}^{\prime} \mathrm{s}$ growth rate has been around $30 \%$ to $40 \%$ per year.

Figure 1 - Evolution of CI\&T's Total Revenue (in BRL thousands)

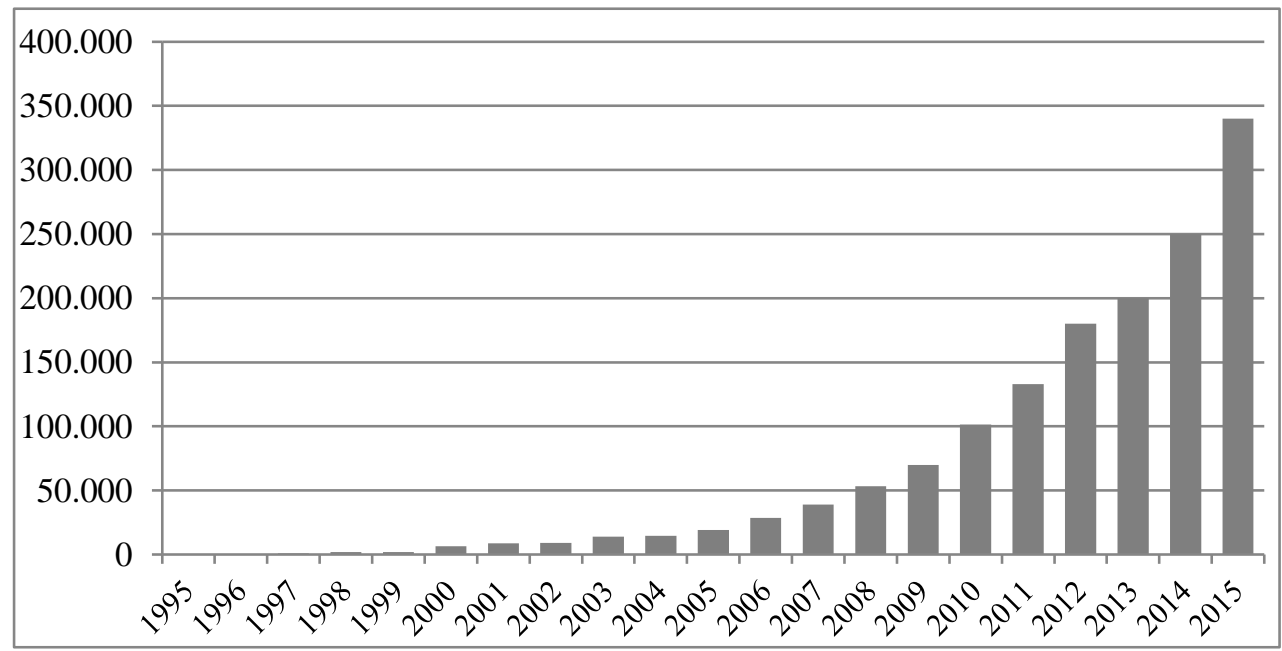

Source: www.anggulo.com.br/camp_tec/palestras/CiT-Polis_new.pdf (1995-2009 data); the data for the other years were obtained in press reports

Note: The numbers are presented in Brazilian currency - BRL - to avoid the distortions caused by abrupt exchange rate fluctuations.

\section{The IT Global Market \& Industry}

In 2015 the global IT market was estimated at 2.2 trillion dollars, led by the U.S. (727 billion), China (227 billion) and Japan (139 billion). Referring specifically to the world market for software and IT services, the U.S. had a share of more than $40 \%$ (Table 1 ).

Brazil is one of the world's major markets: in 2006 it ranked 13th internationally; in 2011 it ranked 10th; in 2012 it reached 7th before dropping to 8th in 2013 and 2014, but it returned to 7th in 2015, equivalent to a value of 60 billion dollars (ABES, 2016). The Latin American market in 2015 was 133 billion dollars, with Brazil standing out with nearly half (45\%) of the investments in the region, followed by Mexico and Colombia. The annual growth of software and IT services in Brazil has been in the double-digits in recent years. However, in 2015 growth was 9.2\%, with $30.2 \%$ for software and $8.7 \%$ for services (ABES, 2015). 
Table 1 - Main World IT Software and Services Markets - 2015 and 2006

\begin{tabular}{|c|c|c|c|c|c|c|c|}
\hline \multicolumn{4}{|c|}{2015} & \multicolumn{4}{|c|}{2006} \\
\hline No. & Country & $\begin{array}{l}\text { Worth (US\$ } \\
\text { billion) }\end{array}$ & Share\% & No. & Country & $\begin{array}{l}\text { Worth (US\$ } \\
\text { billion) }\end{array}$ & Share\% \\
\hline 1 & US & 470 & $41.8 \%$ & 1 & US & 303 & $42.5 \%$ \\
\hline 2 & UK & 83 & $7.3 \%$ & 2 & Japan & 64 & $9.0 \%$ \\
\hline 3 & Japan & 77 & $6.9 \%$ & 3 & UK & 56 & $7.8 \%$ \\
\hline 4 & Germany & 67 & $5.9 \%$ & 4 & Germany & 48 & $6.8 \%$ \\
\hline 5 & France & 48 & $4.3 \%$ & 5 & France & 39 & $5.5 \%$ \\
\hline 6 & China & 34 & $3.1 \%$ & 6 & Canada & 21 & $3.0 \%$ \\
\hline 7 & Canada & 32 & $2.9 \%$ & 7 & Italy & 18 & $2.5 \%$ \\
\hline 8 & Brazil & 27 & $2.4 \%$ & 8 & Australia & 13 & $1.8 \%$ \\
\hline 9 & Australia & 24 & $2.1 \%$ & 9 & Netherlands & 12 & $1.8 \%$ \\
\hline 10 & Italy & 21 & $1.8 \%$ & 10 & Spain & 10 & $1.5 \%$ \\
\hline 11 & Netherlands & 21 & $1.8 \%$ & 11 & China & 10 & $1.3 \%$ \\
\hline 12 & Spain & 18 & $1.6 \%$ & 12 & Switzerland & 9 & $1.3 \%$ \\
\hline 13 & India & 13 & $1.2 \%$ & 13 & Brazil & 9 & $1.3 \%$ \\
\hline 14 & South Korea & 11 & $1.0 \%$ & 14 & Switzerland & 9 & $1.2 \%$ \\
\hline 15 & Russia & 10 & $0.9 \%$ & 15 & South Korea & 7 & $1.0 \%$ \\
\hline 16 & Mexico & 10 & $0.9 \%$ & 16 & - & - & - \\
\hline 17 & Hong Kong & 3 & $0.3 \%$ & 17 & - & - & - \\
\hline \multicolumn{2}{|c|}{ Other countries } & 155 & $13.8 \%$ & \multicolumn{2}{|c|}{ Other countries } & 84 & $11.8 \%$ \\
\hline \multicolumn{2}{|c|}{ Entire World } & 1.067 & 100.0 & \multicolumn{2}{|c|}{ Entire World } & 714 & 100.0 \\
\hline
\end{tabular}

Source: ABES (2016, p.8); Gutierrez (2007). Both sources utilize IDC data.

The IT outsourcing market is usually divided in two segments: information technology outsourcing (ITO) and business process outsourcing (BPO). ITO involves contracting service providers to develop or manage IT functions outside the organization, while BPO consists in contracting third parties to perform backoffice or internal functions (such as accounting), and front-office or customer service activities (such as call center). Table 2 lists some of the ITO and BPO services used by European companies. According to Statistica (2017), the global outsourcing industry had a total revenue in 2016 of approximately 77 billion dollars, of which almost 69\% came from ITO (Table 3). Industry revenues have seen a major drop in 2013 (Figure 2).

Table 2 - Types of Outsourcing Services Used by European Countries - 2013

\begin{tabular}{|l|l|}
\hline ITO & BPO \\
\hline Application development & Call center and customer support \\
Application management & Design and engineering \\
Desktop and workplace management & Facilities management \\
Infrastructure and data center service & Finance and accounting \\
IT helpdesk and support & HR services \\
Testing & Knowledge processes \\
Other ITO services & Legal services \\
& Logistics \\
& Marketing \\
& Payroll services \\
& Procurement \\
& Production and development \\
\hline
\end{tabular}


Table 3 - Global Outsourcing Industry Revenue (US\$ billion)

\begin{tabular}{|l|l|l|l|}
\hline Year & Total & ITO* & BPO** \\
\hline 2010 & 93.1 & 67.8 & 25.3 \\
\hline 2011 & 95.0 & 66.4 & 28.7 \\
\hline 2012 & 99.1 & 62.6 & 36.5 \\
\hline 2013 & 82.9 & 55.2 & 27.7 \\
\hline 2014 & 104.6 & 76.1 & 28.5 \\
\hline 2015 & 88.9 & 63.5 & 25.4 \\
\hline 2016 & 76.9 & 52.9 & 24.0 \\
\hline
\end{tabular}

Source: Statistica (2017)

Notes: ${ }^{*}$ ITO = Information Technology Outsourcing; **BPO = Business Process Outsourcing

Figure 2 - Global Market Size for Outsourced Services

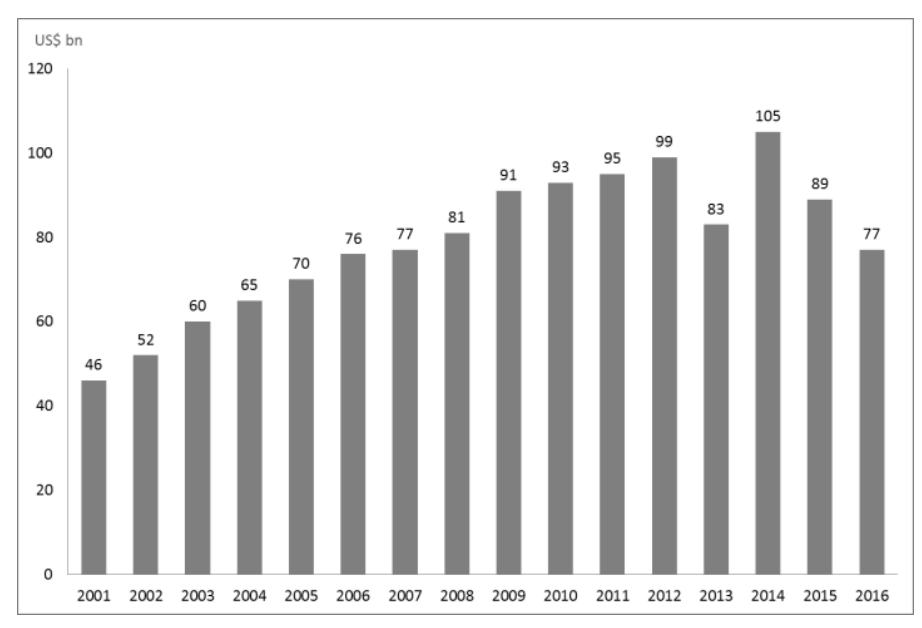

Source: Statistica (2017)

India is the leading player in the global outsourcing industry, but other countries have also positioned themselves to serve this market. An A.T.Kearney (2015) report points out that China and Mexico are alternatives that offer cost advantages, due to lower corporate taxes and interest rates. Bulgaria, Brazil and Egypt are considered rising IT outsourcing locations and strong regional players. Other countries with the potential to become global players, with specialized IT services, are Malaysia, the Philippines, and Poland. Figure 3 presents outsourcing location choices of 140 global companies.

Figure 3 - Outsourcing Location Choices of 140 Global Companies

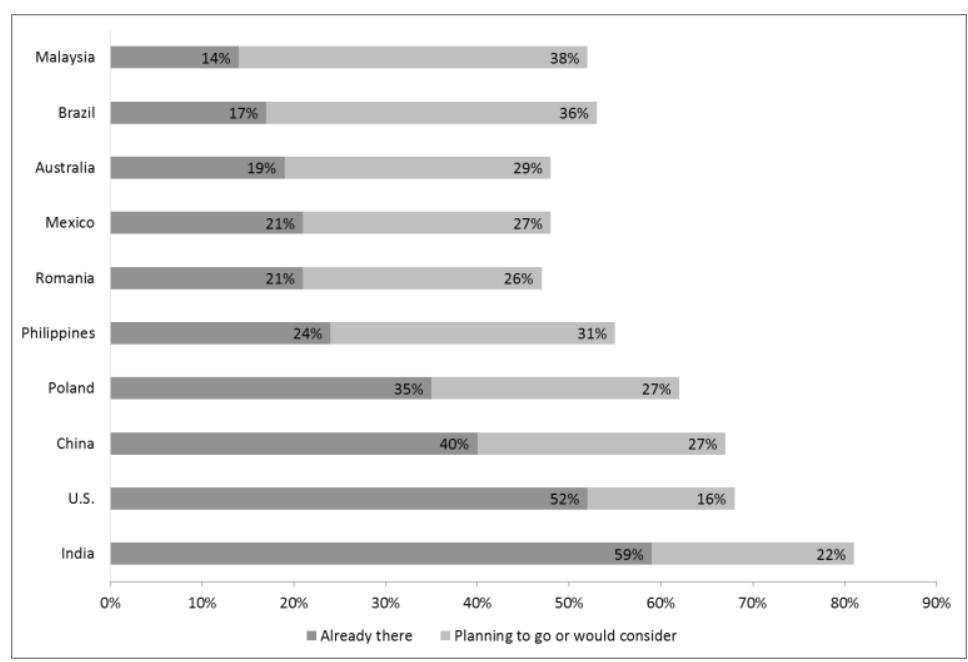

Source: Deloitte (2014) 
Despite the size of the global market for outsourcing services, around $75 \%$ of IT services are performed inside the companies and not delegated to third parties (EY, 2013). Companies that use outsourcing services can be found in a large array of industries. There is some variation among industries, with consumer goods and automotive manufacturers being more willing to outsource, possibly due to lower margins and fierce competition. The most frequent reason for a company to outsource is costrelated, but another important motive is the desire to focus on the firm's core business.

Company managers report several issues in their relationships with their outsourcing service providers (Deloitte, 2016). They complain that providers tend to be more reactive than proactive $(46 \%)$ and not enough innovative (33\%). They are also critical of human resources qualification (23\%), internal integration (22\%) and service quality (20\%). In addition, 29\% report high staff attrition rates, and $13 \%$ terminate the relationship when issues arise.

Several challenges were hovering in the horizon for the global outsourcing industry. First, many companies have decided to bring back some services previously outsourced to their own structure, due to several types of risk, such as political risk, or need to improve control over certain types of activities (including IT). Some specialists consider that many companies may have gone too far in outsourcing services, including some that can be considered part of their core business, or critical to customer satisfaction. Second, the rise of protectionism and anti-globalization moves in developed countries definitely seem to threaten the industry. In fact, several Indian companies have reported the loss of British contracts after the Brexit referendum, and the Indian outsourcing industry as a whole has felt a drop in revenue and profits growth in recent years. Infosys CEO reacted to these changes by warning the company's employees that the firm's survival would be threatened if the company continued to adopt a reactive stance. This opinion was shared by many specialists, to whom the Indian outsourcing industry needs to reinvent itself (Sachitanand, 2017).

\section{The Brazilian IT Industry}

The domestic IT industry grew under the market protection of the IT Law, which lasted for twenty years. When the market protection ended, government programs aimed at supporting the development of the software industry and to boost exports, with only moderate success.

Some of the most prominent areas of the Brazilian IT sector are agribusiness, the aerospace and automotive industries, health, e-commerce, insurance, banking automation, fiscal and tax operations, among others. The financial sector is one of the most important, considered by the World Bank and the Gartner Institute as the most advanced in the world. However, Brazilian market share of software developed in the country is only $21.7 \%$, whereas regarding services, $85.4 \%$ is offered by indigenous companies. Brazilian software exports in 2014 were estimated at $\$ 245$ million and those of services at $\$ 680$ million (ABES, 2016). Table 4 shows the main competitive advantages of Brazil in software and services to serve the U.S. and Western European markets, compared to India and China.

Table 4 - Competitive Advantages of Brazil in IT Software and Services

\begin{tabular}{|c|c|}
\hline Country Advantages & Industry Advantages \\
\hline $\begin{array}{l}\text { - } \quad \text { Low travel and communication costs } \\
\text { - } \quad \text { High cultural compatibility } \\
\text { Time zone closer to the major markets (U.S. } \\
\text { and Western Europe) } \\
\text { - } \quad \text { High productivity }\end{array}$ & $\begin{array}{ll}- & \text { Low incidence of rework } \\
\text { - } & \text { Low management costs } \\
\text { - } & \text { High productivity and knowledge of business } \\
\text { Specialization in financial systems and manufacturing (ERP) }\end{array}$ \\
\hline
\end{tabular}

\section{Going International}

Internationalization started initially by means of a company in California that had a Brazilian partner and an employee who had previously worked for CI\&T. The contract was signed in 2004 to develop a project from Brazil, worth around 35,000 USD. Seven more projects came in sequence, creating a portfolio of experiences that served as a reference for the U.S. market.

The second international client was J\&J. Initially, CI\&T took part in a bid put on by J\&J in Brazil. And even though $\mathrm{Cl} \& \mathrm{~T}$ did not win, the company made a 
good impression in terms of technical expertise and technological innovativeness, leading to a partnership with J\&J's US headquarters, which was looking for partners in Brazil to diversify its competence centers, concentrated till then in India and the U.S.:

\begin{abstract}
"We had suggested an innovative super solution to them [J\&J]. However, they decided to go with SAP because they thought it was safer. But during the process, they were really impressed with CI\&T. When J\&J U.S. wanted to build a development center in Brazil, J\&J's people in Brazil recommended us. And then we received around eight or ten visits by groups of six to ten different people. [..] Until someone there had the guts to make the decision and we signed the contract with Johnson... The original contract was miniscule: only a handful of people. We signed the first contract, the second, and then a string of them. The team kept growing until it totaled 300 people, five or six years later" (Bruno Guiçardi).
\end{abstract}

Despite the size of the project, CI\&T was not J\&J's only supplier. CI\&T had around 300 people connected with $J \& J$, out of a total of four to five thousand people in J\&J's IT department. In spite of the strong expansion of operations in the U.S., CI\&T continued to develop projects remotely, without permanent employees in that country.

Since 1999 the company had been preparing to expand its international exposure. For example, in 2002 it created a website in English, not to sell but to develop its image and start contacts abroad. Another initiative was to take part in creating an export consortium in 2005, which brought together ten companies in the software industry. In 2006 the consortium won the Award for Excellence in Exporting given by the Brazilian Agency for Export Promotion and Investments (Apex-Brasil) due to its brand building efforts in the US, including opening a local office. In Guiçardi's opinion, the consortium per se did not generate many sales, but helped to develop an understanding of the international market. At about the same time, the company hired a consultant to prospect the New York market. The consultant put the partners in touch with potential clients, but the initiative did not result in sales, according to Guiçardi:

"We had a few conversations and... it was really disappointing. They would ask how many people worked for the company and then came the response: 'Oh... well that won't work! We only deal with much larger companies; we don't contract with small ones.' We could see that for large companies the outsourcing game was a whole different ball of wax. So we decided to search for the market that would be the second wave of outsourcing: midsize companies, not large ones."

Thus in 2005 the company decided to open a branch in Philadelphia, Pennsylvania, to prospect more clients, and it became operational in 2006, initially using shared space. Hence it increased its presence in the US, not only with J\&J, but with other companies such as Pfizer, Bayer, Roche, Cadence, Yahoo, etc. The initial choice was due to the fact that J\&J was already in Philadelphia, but it was also based on a market study of the profile of the regional market, according to Guiçardi:

"The decision to go to Philadelphia was based on a market study that we bought. It showed that Philadelphia had one of the highest concentrations of mid-sized companies in the US. There were thousands of companies in the 100 million to one billion dollar range - not too big. So it was a strategic assumption that brought us to Philadelphia - an assumption that in fact never materialized. Actually, with a few exceptions, we couldn't sell to midsize businesses here in the US. We've always sold to large and small businesses... startups, high-technology companies."

In addition, the state of Pennsylvania was strongly encouraging the IT sector, offering incentive programs, a stimulating environment for innovation, and a supply of skilled labor coming from the leading universities in the region. The establishment of Cl\&T's American subsidiary made all the difference in the internationalization process of $\mathrm{Cl} \& \mathrm{~T}$, enabling its acceleration. The choice of men to manage the subsidiary was very careful, as explained by Bruno Guiçardi:

"Since the higher-ups - partners and directors all had the opinion that, since it was a great opportunity, we had to mobilize our best minds. My team here today in the US - the same team that had been sent here over a number of years is a "dream team." They are real talents. At CI\&T we have always believed we should put the best people on the best opportunities."

Later CI\&T opened more offices in the United States. Guiçardi explained: "It was a step by step strategy. We never opened an office in a place where we didn't have a client, a referral." For him, a key element for business opportunities in the U.S. is 
word-of-mouth, from a network of business relationships established by the company over the years:

"What works here in the U.S. is really no different from how the IT business works in Brazil. We sell our services within a sphere of influence that we have established; that is, we can't sell to those who don't know who we are. That is why referrals are essential... So who have we managed to sell to here in the U.S.? To organizations that have someone who has come over from a company that we have already served, or someone who needs some type of service and knows someone who has worked with us. It's a network of referrals. It's really hard - it does happen, but it's rare - to sell to someone who hasn't received a referral about us."

In 2006 C\&IT opened a commercial branch in London in order to serve the European market. The company's board thought that it was also important to be in the Asian market. Thus, in $2009 \mathrm{Cl} \& \mathrm{~T}$ formed a joint venture (Cl\&T Pacific) with a Japanese IT company - Rococo - establishing a Tokyo office and a development center in Ningbo, China, where there are 15 IT universities graduating approximately six thousand experts per year. The development center serves clients in Asia.

"We felt there was an opportunity to expand our presence in Asia by relying on a few clients there, especially J\&J. So we discussed the idea with executives at J\&J and they assured us they were interested since we were already a global vendor for them... We felt that if we were there, it might be possible to drum up business with the same clients; it would be simple to increase the amount of business with current clients in that new geographic area. We went on a commercial mission to find partners because we wouldn't be able to enter the Japanese market without a partner.

We found a company that was interested and we stayed a couple of years 'dating.' A lot of reciprocal visits. And then we finally formed a joint venture with this Japanese company. The office is in Japan, whereas the development center is in China, because in that location [Ningbo] there are a lot of professionals with good training and competitive cost. And Japan is a more structured market... In fact, it is a back-to-back operation: an office in Tokyo and a factory in China. We see the operation as being just one operation" (Bruno Guiçardi).
Rococo Global Technologies, a partner of Cl\&T, was founded in 1994 in Osaka to develop software and manage IT infrastructure and applications. The company has around 300 employees. In addition to the headquarters in Osaka, it has offices in Tokyo, Shanghai and Ningbo (China), and offshore operations in the Philippines. Guiçardi stressed the importance of having a partner in Asia:

"Our sole partnership is at CI\&T Pacific. We didn't think that we could do any business development activity without people with a lot of experience in the market. And it would be difficult to hire such people. So we preferred to partner with someone. Our partner is Japanese... Our Japanese partner was in charge of business development and we were in charge of operations. So we had to build the operation in China. [...] Later on we saw that our assessment had been correct. Without the partnership with the Japanese, we couldn't have entered Japan. So it wouldn't have worked out; the affiliate wouldn't have sold one peanut. The locals wouldn't have agreed to do business if they didn't know we had a partnership with an established Japanese company. [...] Japan functions like a completely different world."

In 2010 the company received $35 \%$ of its revenues from abroad, $88 \%$ coming from the US, $7 \%$ from Europe and 5\% from Asia. In 2012, Cl\&T opened its second development center outside of Brazil, in Buenos Aires, Argentina. The operation in Argentina was incorporated as a wholly-owned subsidiary, without local partnership.

One reason to open the subsidiary was the lower cost of software development in the country. Towards the end of 2012, 20\% of Cl\&T's exports to the US came from its affiliate in Argentina and $80 \%$ from its headquarters in Brazil. As Cesar Gon stated, "On average, our costs in Argentina are still 20\% lower than in Brazil. But the country used to be more attractive." There would be little room for expansion via exports to other Latin American countries: "Exporting to any other country in the region entails a $40 \%$ tariff. All Latin American countries are protectionists" (Drska, 2012b).

In 2013 the company decided to increase its presence abroad and modify its global structure, with the intention of increasing the autonomy of each of the four regions where it operates: Latin America, North America, Europe and Asia. In each region leaders were appointed to act as chief executives, who relocated to their respective areas. According to 
Cesar Gon, it was necessary to maintain a local presence in the major markets. This is required in keeping with the business model of the company, which delivers its services from development centers located in strategic areas of high competence and low cost. However, by 2015, the company decided to close its development center in Argentina, although this decision could be changed in the future. It also acquired Rococo's share in the joint venture in Japan, which became a fully-owned subsidiary. A Brazilian executive with a 25-year business experience in Japan was hired to lead the subsidiary.

\section{Specifics of CI\&T's Internationalization}

\section{Cl\&T works with two concepts:}

- Nearshore, i.e. providing services in neighboring countries, with the expectation that it will benefit both partners that have some kind of proximity: geographic, cultural, linguistic, or time zone; and

- Lean IT - a lean production model created by Toyota in the automotive sector, with a focus on gains in speed and reductions in costs.

In the nearshore model, the number of employees at each foreign location is reduced: only the number of employees required to run business processes or to have more interaction with clients. The technical processes of systems development are located at competence centers, in areas that offer low cost and a good supply of skilled labor, and which are close to clients. In an interview with a Brazilian business newspaper, Cesar Gon, CI\&T's CEO, explained (Drska, 2012a, p. B5):

\begin{abstract}
"CI\&T's idea is to build a network of small global centers to serve its clients in a more personalized way. With a leaner structure, closer to clients, you can get a better understanding of the needs of each business and make a counterpoint to the standard model of Indian companies."
\end{abstract}

This model has been adopted in the IT industry since it started to identify a number of problems with the offshore model with regard to time zone and even cultural differences. The need for development centers closer to end clients (in terms of both time zone and cultural differences) - nearshore - is used as a counterpoint to the Indian strategy, and has been successfully employed by Cl\&T.

One of the means the company uses to effectively reach more potential clients is by using market analysts. Companies like the Gartner Institute and
Forrester are opinion leaders in the IT industry and are more easily listened to by American executives. $C I \& T$ has sought to participate in international rankings as a way to attract attention and become visible in the global market, in addition to obtaining new business opportunities. The company also participated in trade fairs to get more business opportunities when entering new markets. Another promotional tool highly valued by the company is to have a local Public Relations (PR) advisor:

"Our marketing budget doesn't include advertising. Our biggest return on investment is in PR. In Brazil people think that CI\&T is a lot bigger than it actually is because of all the 'noise' it makes. That's the result of successful PR. It's cheap and more effective... but you need to have stories to tell. And thank God, CI\&T does have stories to tell!"

The company does not consider marketing research very useful. It places a higher value on knowledge gained through experience in the country, as Guiçardi revealed: "Nothing can replace the knowledge and skill that the company is creating with its on-site presence, being right there... The best advice I can give business people is: stop doing market research and get there."

Prices are usually established taking costs and margins into account. A major obstacle has been the currency fluctuation, because it impacts the competitiveness of the company overseas. Cesar Gon, believes that to be in the U.S. market works as a natural hedge against currency fluctuations. In addition, it helps the firm to be constantly aware of new technological developments, a source of competitive advantage to serve Brazilian clients. For example, while the main projects in the U.S. relate to machine learning, mobility solutions are still more demanded by Brazilian clients. And when Brazilian companies started to demand mobile solutions, Cl\&T had already substantial experience acquired in the U.S. market.

\section{Future Perspectives}

CI\&T's presence abroad is seen as fundamental, as Guçardi pointed out:

"For the company, our perception of the worth of the international arena has changed. It is the source of innovation for CI\&T as a whole. Innovations have come from it: innovations of delivery, competitiveness, tools, methods... That's where everything comes from and where it also ends up - using and implementing for clients in 
Brazil. This change in perception has occurred over time. In the United States, the main benefit we got was in gaining a competitive edge. The US market is absolutely more competitive than Brazil. So we have to bring that competitive edge to the company, not only in the US, but worldwide."

The company's plan for the next years involved maintaining the upward trend of recent years, despite the economic crisis in Brazil, the growth of protectionism in the U.S., and the challenges faced by

\section{References}

ABES - Associação Brasileira das Empresas de Software (2016). Mercado brasileiro de software: panorama e tendências, 2015. São Paulo: ABES.

A.T.Kearney (2015). The rising stars of IT outsourcing. Available at: https://www.atkearney.com/researchstudies/global-services-location-index/related-full/lasset publisher/VpbMOes4s10c/content/the-risingstars-of-it-outsourcing/10192.

Cyrillo, M.M. (2014). Agile in the enterprise: to succeed, avoid the fundamentalists. March 29, 2014. Available at: https://venturebeat.com/2014/03/29/agilein-the-enterprise-to-succeed-avoid-the-fundamentalists/.

Deloitte (2014). Deloitte's 2014 global outsourcing and insourcing survey. Available at: https://www2.deloitte.com/content/dam/Deloitte/us/Do cuments/strategy/us-2014-global-outsourcing-insourcingsurvey-report-123114.pdf.

Deloitte (2016). Deloitte's 2016 global outsourcing survey. Available at https://www2.deloitte.com/content/dam/Deloitte/nl/Doc uments/operations/deloitte-nl-s\&o-global-outsourcingsurvey.pdf.

\section{About Authors}

Sylvia T. de Almeida Moraes - Pontifícia Universidade Católica do Rio de Janeiro - PUC/RJ, Rio de Janeiro, (Brasil).E-mail: sylvia.tamoraes@gmail.com Orcid id: https://orcid.org/0000-0001-6651-0933

Angela da Rocha - Pontifícia Universidade Católica do Rio de Janeiro - PUC/RJ, Rio de Janeiro, (Brasil). E-mail: amc.darocha@gmail.com Orcid id: https://orcid.org/0000-0002-8409-6884 the global outsourcing industry. It also intended to keep a third of its workforce abroad to serve the US and Japan markets. Cl\&T projected a new cycle of growth of more than $20 \%$ per year by offering valueadded services and establishing higher levels of performance in new international operations. Top management was particularly anxious to define the steps necessary to accelerate the firm's internationalization in order to turn CI\&T into a relevant global player.

Drska, M. (2012a). Brasil reduz custo de produção, mas foco ainda são os EUA. Valor, 29.10.2012. Available at: http://www.valor.com.br/empresas/2883502/brasilreduz-custo-de-producao-mas-foco-ainda-sao-os-eua.

Drska, M. (2012b). Cl\&T investe em novo centro de desenvolvimento na Argentina. Valor, 15.02.2012, Caderno Empesas, p.B5.

EY (2013). Outsourcing in Europe. Available at: http://www.ey.com.br/Publication/vwLUAssets/Outsourci ng in Europe 2013/\$FILE/EY-outsourcing-survey.pdf.

Gutierrez, R.M.V. (2007). Complexo eletrônico: O setor de software brasileiro e o Prosoft. BNDES Setorial, 26:2562, setembro 2007. industry stares at an uncertain future. January 15, 2017. Available at http://economictimes.indiatimes.com/tech/ites/indiastechnology-vendors-paddling-shakyboats/articleshow/56543653.cms.

Statistica (2017). Global market size for outsourced services. Available at:https://www.statista.com/statistics/189788/globaloutsourcing-market-size/
Sachitanand, R. (2017). India's $\$ 150$ billion outsourcing 


\section{EMPREENDEDORISMO INTERNACIONAL EM UMA EMPRESA LÍDER DE SERVIÇOS DE SOFTWARE: O CASO DA CI\&T}

Sylvia T. de Almeida Moraes, Angela da Rocha

Pontifícia Universidade Católica do Rio de Janeiro - PUCRJ, Rio de Janeiro, (Brasil)

\section{DETALHES DO ARTIGO}

\section{Histórico do Artigo:}

Recebido: 16 de Outubro de 2018

Aceito: 21 de Agosto de 2019

Disponível online: 01 de jan. de 2020

Sistema de revisão "Double blind

review"

\section{Editor Científico}

Ilan Avrichir

\section{Palavras-Chave}

Empreendedorismo

Países emergentes

Internacionalização

Indústria de Software

Brasil

\begin{abstract}
RESUMO
Objetivo - Este caso visa discutir em que medida uma empresa de um país emergente, o Brasil, pode se tornar um participante importante no cenário global da indústria de software.

Principais resultados - A CI\&T é uma das empresas brasileiras de TI de maior sucesso no estabelecimento de uma posição no mercado externo. O caso oferece uma descrição detalhada do processo de internacionalização da empresa e discute como a empresa pode desenvolver sua internacionalização, enfrentando os desafios e as oportunidades de maior expansão.

Relevância/originalidade - Este caso de ensino oferece uma situação real de uma empresa de TI do Brasil que desenvolveu uma estratégia internacional bem-sucedida.

Contribuições teóricas/metodológicas - O caso contribui para promover o entendimento dos três principais passivos de empresas de países emergentes: passivo decorrente de ser estrangeiro, passivo decorrente de não participar de redes e passivo decorrente do tamanho.

Contribuições sociais / para a gestão - O caso pode ser usado em cursos de negócios internacionais para melhorar as habilidades gerenciais de estudantes e executivos.
\end{abstract}

\section{EMPRENDIMIENTO INTERNACIONAL EN UNA EMPRESA LÍDER DE SERVICIOS DE SOFTWARE: EL CASO DE CI\&T}

\section{DETALLES DEL ARTÍCULO}

Historia del Artículo:

Recibido: 16 Octubre 2018

Aceptado: 21 agosto 2019

Disponible en línea: 01 de enero 2020

Sistema de revisão "Double blind review

Editor Científico

Ilan Avrichir

\section{Palabras-clave: \\ Emprendimiento \\ Países emergentes \\ Internacionalización \\ Sector del software \\ Brasil}

\begin{abstract}
RESUMEN
Objetivo - Este caso visa discutir em que medida uma empresa de um país emergente, o Brasil, pode se tornar um participante importante no cenário global da indústria de software.

Principais resultados - A CI\&T é uma das empresas brasileiras de TI de maior sucesso no estabelecimento de uma posição no mercado externo. O caso oferece uma descrição detalhada do processo de internacionalização da empresa e discute como a empresa pode desenvolver sua internacionalização, enfrentando os desafios e as oportunidades de maior expansão.

Relevância/originalidade - Este caso de ensino oferece uma situação real de uma empresa de TI do Brasil que desenvolveu uma estratégia internacional bem-sucedida.

Contribuições teóricas/metodológicas - O caso contribui para promover o entendimento dos três principais passivos de empresas de países emergentes: passivo decorrente de ser estrangeiro, passivo decorrente de não participar de redes e passivo decorrente do tamanho.

Contribuições sociais / para a gestão - O caso pode ser usado em cursos de negócios internacionais para melhorar as habilidades gerenciais de estudantes e executivos.
\end{abstract}

\section{Cite it like this:}

de Almeida Moraes, S., \& da Rocha, A. (2020). International Entrepreneurship at a Leading Brazilian Software Services Provider: The Case of CI\&T. Internext, 15(1), 118-133. doi:http://dx.doi.org/10.18568/internext.v15i1.479 


\section{TEACHING NOTE}

\section{Case Objectives}

This case presents the situation of a software firm from an emerging country, Brazil. There are two approaches - separate or combined - that can be used by instructors in a classroom discussion.

- $\quad$ The first approach is more analytical and consists in discussing how an emerging market firm can compete on the global stage of the software industry. In order to explore this issue, the case invites the student to analyze the competitive advantages of the firm CI\&T, using Cuervo-Cazurra \& Un's framework, and its disadvantages in light of the three major liabilities of emerging country firms - liabilities of foreignness, liabilities of outsidership and liabilities of smallness.

- The second approach is more decision-oriented and consists in focusing on CI\&T's next step for building a global leadership position. If the instructor chooses this approach, he/she can proceed through the general or analytical issues more quickly and give more time to the decision-making aspects of the case.

\section{Target Audience}

The case was developed for use in advanced graduate courses in International Business or Strategy.

\section{Questions for Discussion}

The following questions are suggested for classroom discussion:

\section{General (analytical) questions:}

- What is the strategic problem faced by CI\&T's directors? What is your assessment of Cl\&T's strategic ambitions? What factors make such ambitions feasible? What factors make them unfeasible?

- What are CI\&T's competitive advantages and disadvantages for achieving its long term goals? Are CI\&T's advantages transferable to other countries?

- Do an analysis of the internationalization strategy adopted by the company to date. What are the entry modes used by the company? What is the rationale behind the adoption of each of them?

Focused (decision-oriented) questions:
- How far can CI\&T's internationalization go with its present strategy and at its present pace?

- What should the next steps for the company be to accelerate its internationalization process? Over the next two years? The next five years?

\section{Case Analysis}

\section{Strategic Problem}

CI\&T still needs to grow and expand internationally before becoming a relevant competitive player on the global scene. Among the factors that drive the company to strive for a worldwide presence are:

(i) the founders' desire from very early on to build a global company;

(ii) the difficulties arising from Brazil not being recognized in the international market as a software producer, or not having an image associated with high tech, which makes winning multinational clients difficult;

(iii) the understanding that the company's international presence, particularly in highly competitive markets, places it at the forefront of technological trends in the industry, making it internationally competitive;

(iv) the need to follow major clients, not only foreign multinationals (such as J\&J), but also Brazilian companies which have become international. Even with all the technological advances and with products that can be developed and delivered at a distance, the company's presence in the foreign country where the client is can make all the difference in terms of customer service, prospecting the market, etc. In addition, its presence in the market enables it to acquire experiential knowledge, which it could not do otherwise, and which is critical to the success of any business in foreign markets;

(v) the need to reduce dependence on the Brazilian market, given the wild monetary exchange rate fluctuations, which affect the company's competitiveness. In particular, the overvaluation of the Brazilian real against the dollar through 2014 made it difficult for the company to compete with international competitors in terms of cost, but this reality changed towards the end of 2014, opening up new prospects for exports of software and IT services from Brazil.

Theoretical Background for Analyzing CI\&T's Competitive Advantages and Disadvantages 
We suggest two frameworks for analyzing a firm's competitive advantages and disadvantages: the first derives from the work of Cuervo-Cazurra \& Un (2004), which provides a very detailed description of possible sources of competitive advantages $e$ disadvantages; the other derives from the work of Johanson and Vahlne (2009), which focuses on liabilities. Actually, both analyses may be used if the instructor has enough time during the session. We used the case in the classroom to develop the students' analytical skills concerning the competitive advantages of a firm involved in International Business.

Figure 1 presents a visual summary of CuervoCazurra \& Un's framework. It can be drawn on the board to make it easier for students to memorize different sources of competitive advantage and it can also help with the analysis.

FIGURE 1 (TEACHING NOTE) - Theoretical Framework of Cuervo-Cazurra and Un (2014)

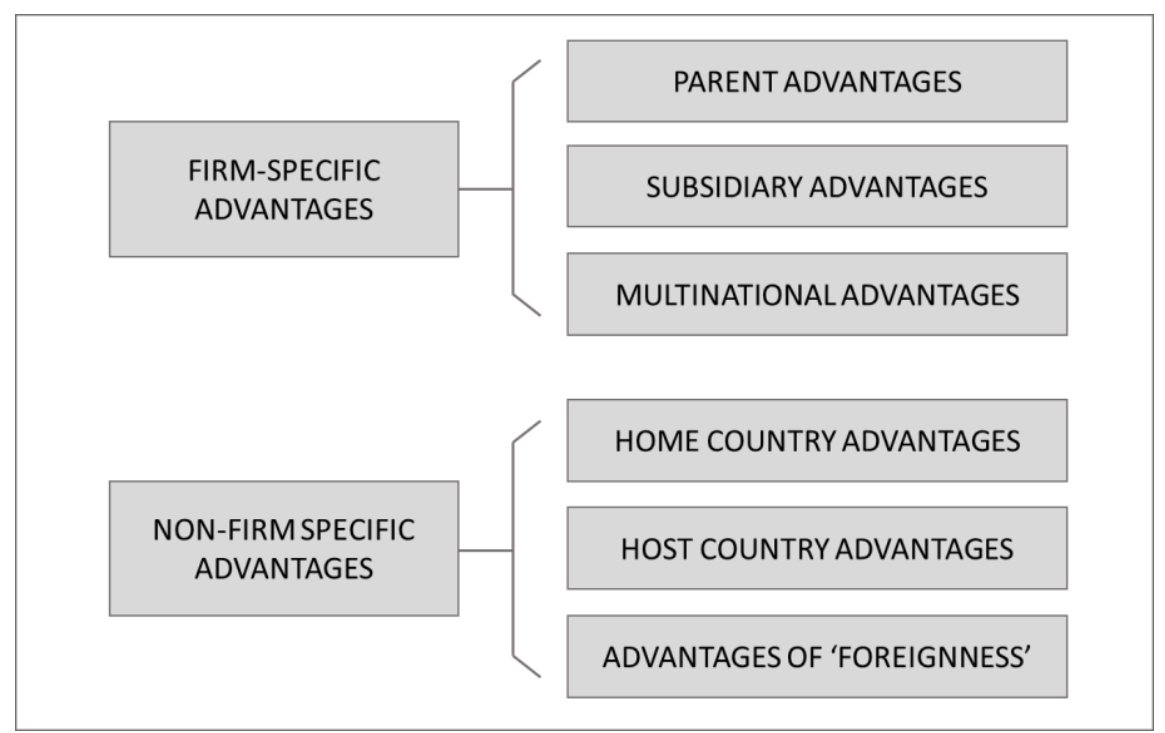

The competitive advantages of Cl\&T can be analyzed both from the perspective of the advantages of the home country (in this case, Brazil) and of the host country (U.S., Japan, China, Argentina), and also from the perspective of the firm's resources and capabilities, either at its headquarters in Brazil or at a subsidiary. Table 1 presents a summary of the issues raised by students in a class discussion.

Regarding the problems associated with Brazil, it is also important to highlight the currency issue, which merits discussion. The exchange rate problem is inherent to international business, but Brazilian entrepreneurs have been facing wild fluctuations in the dollar exchange rate in relation to the national currency, a fact that makes unviable the competitiveness of entire industries such as footwear and furniture, where price is a fundamental factor for competition.

The country-image issue is particularly important in the internationalization process of Brazilian tech companies because Brazil is seen to be rich in natural resources, but low in technological know-how, although this image started to change in 2010, when Brazil's reputation began developing on the world scene. Regarding this matter, any change depends on institutional and governmental action in foreign markets. The measures taken by $\mathrm{Cl} \& \mathrm{~T}$ to overcome this difficulty included partially disassociating its image from that of Brazil by establishing subsidiaries abroad.

See the following table regarding the analysis of CI\&T's specific advantages and disadvantages when compared with its international competitors. 
TABLE 1 (TEACHING NOTE) - CI\&T's Advantages and Disadvantages

\begin{tabular}{|c|c|}
\hline CI\&T's ADVANTAGES & CI\&T's DISADVANTAGES (LIABILITIES) \\
\hline $\begin{array}{ll}\text { Parent Advantages in Brasil } \\
- & \text { Size (large for Brazil), reputation } \\
\text { - } & \text { Organizational culture (values, sense of mission, } \\
& \text { strategic intent) } \\
- & \text { Access to government resources (BNDES) } \\
- & \begin{array}{l}\text { Experience in competing directly with global } \\
\text { players }\end{array}\end{array}$ & \\
\hline $\begin{array}{l}\text { Subsidiary Advantages in the U.S. } \\
\text { - Initially, only the relationship with J\&J } \\
\text { - Later, acquisition of experiential knowledge, } \\
\text { development of other business networks } \\
\text { - In Philadelphia: access to incentives, innovation- } \\
\text { supportive environment and qualified labour }\end{array}$ & $\begin{array}{l}\text { Subsidiary Disadvantages in the U.S. } \\
\text { - liability of foreignness (lack of market knowledge) } \\
\text { - liabilities of outsidership (no network, except J\&J) } \\
\text { - liability of smallness (most clients are large firms) }\end{array}$ \\
\hline $\begin{array}{l}\text { Subsidiary Advantages in Japan } \\
\text { - Ability to overcome liabilities of outsidership and } \\
\text { foreignnessç establish partnership with middle-sized } \\
\text { firm } \\
\text { - Ability to take advantage of already established } \\
\text { networks in Brazil and the U.S. }\end{array}$ & $\begin{array}{l}\text { Subsidiary Disadvantages in Japan } \\
\text { - liability of outsidership (no Japanese network; need } \\
\text { of a partner to do business in Japan } \\
\text { - liability of foreignness (lack of market and business } \\
\text { practices knowledge) }\end{array}$ \\
\hline $\begin{array}{l}\text { Subsidiary Advantages in China } \\
\text { - Access to low-cost highly-qualified labour }\end{array}$ & $\begin{array}{l}\text { Because CI\&T does not intend to sell in China but is } \\
\text { focused on production, no important disadvantages } \\
\text { regarding that country. }\end{array}$ \\
\hline \multicolumn{2}{|l|}{ Subsidiary Advantages in Argentina } \\
\hline $\begin{array}{l}\text { Multinational Advantages } \\
\text { - Experience in international business } \\
\text { - Ability to develop business networks }\end{array}$ & \\
\hline
\end{tabular}

The instructor may also focus on the liabilities that an emerging market company faces. These are analyzed in the work by Johanson \& Vahlne (2009), as well as in several other works. While the first analysis focuses on the advantages, the second focuses on the disadvantages (or liabilities).

The three disadvantages (liabilities) are particularly interesting and can generate good classroom discussion. The term liabilities of foreignness can be translated as liabilities arising from being a foreigner, and it includes unfamiliarity with market characteristics, business practices, etc. in a foreign country, compared with rival companies already operating in that market. The term Liabilities of outsidership refers to not belonging to existing business networks in a given country. Lastly, liabilities of smallness refers to company size.

Note how CI\&T handled these disadvantages: (i) it focused initially on small and medium enterprises as clients in order to overcome the liabilities of smallness; (ii) it hired consultants and did market research in order to overcome the liabilities of foreignness; (iii) but most importantly, it inserted and developed business networks for its international operations in order to overcome the liabilities of outsidership.

The first two strategies we adopted were modified later, first because the clients CI\&T managed to acquire ended up being either small or large; second, because its business networks demonstrated greater importance both in the U.S. market and in Japan. Unfamiliarity with the way of doing business in each country could only be overcome by means of knowledge acquired in the market - experiential knowledge - as recommended by the Uppsala model (Johanson \& Vahlne, 1977). The use of networks enabled the company to build its reputation in its markets. At first, the fact that it already had good examples of projects developed with a client from California led to the first contract with J\&J. Then, CI\&T used J\&J and projects from Brazil as a reference. 
Success in serving J\&J leveraged sales, both within J\&J's own network, and in networks of other companies from various sectors. Another way to break the barrier of unfamiliarity in the market was the one CI\&T used in Japan by forming a joint venture with a company that already had a client base in that country.

Strategic Decisions in the Internationalization Process

Different entry modes due to the characteristics of the markets - CI\&T used four main forms of internationalization, combining them creatively: internationalization by utilizing the network of a multinational (J\&J); internationalization by opening offices abroad (U.S. and the U.K.); internationalization by opening development centers (software factories) abroad (Argentina and China); and internationalization by means of joint venture (Japan). The input mode and trajectory in each market varied due to the country's characteristics and the role assigned to the branch at the time. Highly different cultures require partnerships; countries with free competition, less bureaucracy and similar cultures are more hospitable to entrepreneurs.

Planned decisions versus emerging decisions Also regarding other decisions involved in the internationalization process, CI\&T opted for a contingency model. Until 2013, decisions were made based on the opportunities that appeared, without a formal, long-term strategy. These decisions had a step-by-step character, and were made as events played out (Johanson \& Vahlne, 1977) and by means of effectuation, i.e., decision-making in an emerging way (Saravsthy, 2001). The example of CI\&T's entry into the US does a good job of illustrating the stepby-step process, as well as decision-making based on effectuation.

The use of networks in internationalization - CI\&T actively used various types of networks to expedite and facilitate its internationalization. The most important network for the company's internationalization was J\&J's, which served for initially accessing both the U.S. market and the Asian market. In the use of these social networks, it becomes clear that investing in small contracts with large companies can leverage new business, both within a company's network and with new clients. Furthermore, the company established its own network of relationships (and references) in North America by successfully providing services to clients. In fact, the importance attributed by the company to business networks met the propositions supported by Johanson \& Vahlne $(2009,2013)$. Finally, the company's former employees became a valuable asset as sources for referrals.

TABLE 2 (TEACHING NOTE) - Timeline of CI\&T Internationalization

\begin{tabular}{|l|l|}
\hline Year & Event \\
\hline 1995 & Founding of CI\&T; beginning of the project with IBM \\
2001 & Creation of the international website \\
2004 & Contract with a company in California \\
2005 & Contract with Johnson \& Johnson \\
2006 & Decision to open a subsidiary in Philadelphia \\
2009 & Opening of offices in Philadelphia and London \\
2012 & Joint Venture in Japan and opening of a competence center in China \\
2013 & Opening of a competence center in Buenos Aires \\
2014 & Reorganization of the international framework \\
2015 & Emphasis on international expansion \\
2015 & Closing of the competence center in Buenos Aires \\
\hline
\end{tabular}

\section{Future Strategy}

Despite the success of Cl\&T's strategy for becoming a respectable player in Brazil, the firm is still too small compared with other global players. In addition, its pace of internationalization is too slow. If the firm's management really intends to add more depth to its international operations, it will have to make substantial strategic changes. If it does not, the firm will remain a peripheral competitor in the global arena.

For the company to achieve its long-term goals, it is essential that a strategic internationalization plan be developed and specific goals established. In particular, the strategy to be adopted by the 
company should take into account the expansion of its international operations, reducing, in relative terms, the share of earnings from Brazil. Participants should be encouraged to propose bolder steps that will take the company beyond the gradual and cautious internationalization that has been its hallmark so far, and to discuss to what extent such bold decisions would involve excessive risks for the company. However, it should be clear that, without taking some risks, the company will not be able to fulfill its founders' dream of becoming a globally relevant company in the IT industry in the near future.

Following are $t$ some of the ideas that emerged in a graduate class.

\section{Main Actions Suggested}

- The company should consider moving its headquarters to the US. This would require a major change in its organizational structure and operations, as well as the transfer of top management to that country. Advantages would be: ease of doing business, access to

\section{Teaching Note References}

Cuervo-Cazurra, A. \& Un, C.A. (2004). Firm-specific and non-firm-specific sources of advantage in international competition. In: Ariño, A., Ghemawat, P., \& Ricart, J.E. Creating value through international strategy. London, Palgrave Macmillan.

Johanson, J., \& Vahlne, J.-E. (1977). The internationalization process of the firm: a model of knowledge development and increasing foreign market commitments. Journal of International Business Studies, 8(1), 23-32.

Johanson, J., \& Vahlne, J.-E. (2009). The Uppsala Internationalization Process Model revisited: From liability of foreignness to liability of outsidership. Journal of International Business Studies, 40(9), 1411-1431. technology and know-how, access to financing, etc. Also, such a move would reduce the liabilities of foreignness, because the firm would be seen as a US company.

- $\quad$ The company could open an R\&D subsidiary in the US, in Silicon Valley, as another major Brazilian software company did. This move would make it easier for CI\&T to have freer access to technology and knowhow, and would also serve as an indication of its innovativeness.

- The company should go public in order to have access to the resources it needs to grow faster (perhaps an IPO in the US).

\section{Methodology for Case Development}

The case is based on primary and secondary sources. The primary sources were three interviews conducted with the company's top management between 2013 and 2016. The secondary sources were the company's website, documents provided by the respondents, information on the Internet, and articles published in newspapers and business magazines.

Johanson, J., \& Vahlne, J.-E. (2013). The Uppsala model on evolution of the multinational business enterprise - from internalization to coordination of networks. International Marketing Review, 30 (3), 189210.

Saravasthy, S.D. (2001). Causation and effectuation: towards a theoretical shift from economic inevitability to entrepreneurial contingency. Academy of Management Review, 26(2), 243-288. 